\title{
Comparing Knowledge and Opinions on Depression among Nurses in the Health Services
}

\author{
Comparando conocimientos y opinión sobre depresión entre enfermeros de \\ los servicios de salud \\ Antonia Regina F. Furegato, Mariluci C. Ferreira da Silva Candido and \\ Moacyr Lobo da Costa Jr.
}

Department of Psychiatric Nursing and Human Sciences, College of Nursing, University of São Paulo at Ribeirão Preto, Brazil. furegato@eerp.usp.br

Received $14^{\text {th }}$ June $2007 /$ Sent for Modification $17^{\text {th }}$ December 2007/Accepted $20^{\text {th }}$ December 2008

\section{ABSTRACT}

Objective This study aimed to compare nurses' knowledge and opinion about depression.

Method Sample consisted of 101 nurses in the basic health care network in two cities in the state of São Paulo (Brazil). Subjects answered two questionnaires presented by WHO about knowledge and viewpoints regarding depression. Projects were approved by the Ethics Committee.

Results The profile reveals that graduation time of Group A (Ribeirão Preto), with 28 subjects, is longer than Group B (São José do Rio Preto), with 73 subjects, and work mobility is higher for Group A. There were significative differences between the two groups $(T=0,012$ and $T=0,666)$ in these questions. Group $B$ showed greater interest in mental health. No significant differences occurred between the two groups, neither in relation to the knowledge nor in their opinion about depression (Med 7,0 and 7,3). Nevertheless, it was observed lack of specific knowledge, need of updating, lack of experience and unawareness of the importance of their therapeutic role for depressed patients.

Conclusions There are differences in the profile of the two groups; however, there are no significant differences in their knowledge and opinion about depression. In both groups deficit of knowledge and unawareness of nurses about importance of their therapeutic role in depression is observed.

Key Words: Depression, nursing, mental health, primary care (source: MeSH, NLM).

\section{RESUMEN}

Objetivo Comparar los conocimientos y opinión de enfermeros acerca de la depresión. Método Fueron parte de la muestra 101 enfermeros de unidades básicas de salud en dos ciudades del estado de São Paulo, Brasil. Los sujetos respondieron a dos cuestionarios presentados por la OMS acerca del conocimiento y puntos de vista sobre la depresión. Los proyectos fueron aprobados por el Comité de Ética. 
Resultados El perfil muestra 28 sujetos del Grupo A (Ribeirão Preto) con más tiempo de graduado y más movilidad en el trabajo que los 73 del Grupo B (São José do Rio Preto), con diferencias significativas entre los dos grupos $(T=0,012$ y $T=0,666)$ en esas cuestiones. El Grupo B se mostró más interesado en salud mental. Tanto en el conocimiento como en la opinión sobre la depresión no hubo diferencias significativas entre los dos grupos (Med 7,0 y 7,3). Sin embargo, se observó, en las respuestas de los enfermeros, carencia de conocimientos específicos, falta de actualización, falta de vivencia y desconocimiento de la importancia de su papel terapéutico junto al paciente deprimido.

Conclusiones Hay diferencias en el perfil de los dos grupos, pero sin diferencias significativas en el conocimiento y en la opinión acerca de depresión. En los 2 grupos se observa que hay déficit de conocimiento y que los enfermeros desconocen su papel terapéutico en la depresión.

Palabras Clave: Depresión, enfermería, salud mental, cuidados primários. (fuente: DeCS, BIREME).

\section{RESUMO}

Comparando conhecimentos e opinião sobre depressão entre enfermeiros de serviços de saúde

Resumo Este estudo objetivou comparar conhecimentos e opinião de enfermeiros sobre depressão.

Método Fizeram parte da amostra 101 enfermeiros de unidades básicas de saúde em duas cidades paulistas que responderam a dois questionários apresentados pela OMS sobre conhecimento e pontos de vista sobre depressão. Projetos aprovados em Comitê de Ética.

Resultados $O$ perfil mostra 28 sujeitos do Grupo A (Ribeirão Preto) com mais tempo de formado e mais mobilidade no trabalho do que os 73 do Grupo B (São José do Rio Preto) com diferenças significativas entre os 2 grupos $(T=0,012$ e $T=0,666)$, nestas questões. O Grupo B mostrou-se mais interessado em saúde mental. Tanto no conhecimento como na opinião sobre depressão não houve diferenças significativas entre os 2 grupos (Med 7,0 e 7,3). Entretanto, observou-se nas respostas dos enfermeiros, falta de conhecimentos específicos, falta de atualização, falta de vivência e desconhecimento da importância do seu papel terapêutico junto ao paciente deprimido.

Conclusões Há diferenças no perfil dos dois grupos porém sem diferenças significativas no conhecimento e na opinião sobre depressão. Nos 2 grupos observa-se que há déficit de conhecimento e que os enfermeiros desconhecem seu papel terapêutico na depressão.

Palavras Chave: Depressão, enfermagem, saúde mental, cuidados primários (fonte: DeCS, BIREME).

7 he depressive disorder is both a health and a social problem. In addition to the personal suffering and the serious risk of suicide, it is one of the main causes of incapacitation to work, to study and to perform other social functions as well (1-5). 
The high prevalence of depression in the population, in all phases of the vital cycle, and the high search for assistance by individuals with depressive symptoms, make the recognition of this disease and its multiple aspects extremely important to all health professionals, especially, those who act in the primary health care (1$8)$.

Despite the great number of people suffering of depressive disorders, it is frequently observed the sub-diagnosis and inadequate treatments in all levels of the health system (1-4).

Until recently, the knowledge and management of mental problems were responsibilities of the manicomial institutions only. The sick people used to be confined in psychiatric institutions. Few nurses got interested in this field and the social and scientific investments in this area were limited. This situation reflects the stigma the society (clients, health professionals and community) stills carries in its attitudes regarding the mental disorder (9-11).

The health assistance in Brazil is organized through the SUS - Single Health System, and functions in regionalized units. These units are responsible for health promotion, emergency consultations and preventive follow up in the basic health areas (woman, child, adult and elderly). The SUS counts with the support of the PSF - Family Health Program, with professionals of generalist backgrounds (nurses, physicians and health agents) and assist the population in its regional area. This system (SUS) is interconnected to the secondary and tertiary levels in outpatient clinics, emergency, hospitalization and rehabilitation units.

Because of the changes caused by the psychiatric deinstitutionalization and reorganization of the health services, professionals have encountered mental disorders in all clinics and health care units.

However, the mental health teaching did not follow the pace of the reform. In its majority, mood disorders was just one topic of the theoretical class and/or a quickly experience with confined patients. There was little investment to the preventive teaching; future professionals were not alerted about the importance to observing the signs and symptoms that indicate these disorders neither about the efficacy of adequate management (forwarding, treatments and care) of diagnosed cases (12-13).

As psychiatric nursing professors we are concerned regarding the education of new nurses as well as knowledge updating of nurses who are in the practice, 
because these professionals will eventually encounter depressed people in all levels and areas of the health care.

This concern found a echo in a project of the PAHO/WHO (1) which has stimulated training of nurses of the basic care network to identify and manage depression.

From the assumption that the nursing education is deficient and that the nurse can have equivocated conceptions about depression, we propose to investigate, in a systemized way, the knowledge and opinion of this professional.

\section{MATERIAL AND METHOD}

Study type: from a descriptive approach, we used tests (questionnaires and scales) applied on the basis of psychometry.

Place: This research was realized in 2 cities in São Paulo State (Ribeirão Preto and São José do Rio Preto). The $1^{\text {st }}$ site was chosen by PAHO when inviting faculty of the Department of Psychiatric Nursing and Human Sciences at the University of São Paulo at Ribeirão Preto College of Nursing to realize the research which, besides identifying nursing knowledge and opinions, about depression. In the second site (São José do Rio Preto), we used the same instruments (PAHO authorized us to replicate the research) that results in a master study.

Subjects: In Ribeirão Preto, there were 28 basic health network service posts, with 180 working professionals; each service selected only one nurse to be included in the study sample (Group A). In São José do Rio Preto region, from the 80 nurses that attend the basic health network care, 73 participated in this study (Group B).

Ethics: The 2 projects were approved by the Research and Ethics Committee of the University of São Paulo at Ribeirão Preto College of Nursing and were authorized by the respective Municipal Health Secretariats. After receiving explanations about the aims and procedures, the participating nurses signed the Informed Consent.

Instruments: The instruments used in this study ( $\mathrm{e}$ e b) were created, tested and presented by PAHO/WHO as part of the "Generalist nurse training for depression identification and management" project (1). 
a. Knowledge about depression. Questionnaire consisting of 12 questions about depression concept, diagnosis, treatment and nursing care. Each question contains 5 alternative answers.

b. Viewpoints on depression, a Likert-scale format, with 10 affirmations indicating subject opinion about depression in a 0 (disagreement) to 9 (agreement) graduation.

By means of these instruments, the subjects also provided information about their own identification and work context, as well as about their interest by mental health area and depression.

Data collection: In Ribeirão Preto, data were collected by faculty and graduate students at the respective 28 Basic Health Units. In São José do Rio Preto, data were collected by one nurse, undergraduate. At both sites, instruments were self-responded in the presence of the applying nurses.

Analysis: Statistic analysis made it possible to compare the 2 group profiles. The Mann Whiney test allowed us to compare the answers given by the 2 groups of nurses in relation to knowledge and opinion about depression.

\section{RESULTS}

Subject profile, context of the work and interest

In Group A, nurses' research participation was low $(15,6 \%)$ in total, in spite of 1:1 representativeness with respect to the amount of UBS-Basic Health Units in Ribeirão Preto.

In São José do Rio Preto (Group B), participation rate was 91,25 \%. The data collection took an average of 15 minutes to answering the 2 tests (Knowledge and Opinion).

Participant age in Group A varied from 33 to 48 years (50\% concentrated between 33 and 37 years), all of which were female. In Group B the age ranged from 24 to 56 years ( $45 \%$ under 33 years and $30 \%$ between 38 and 44 years), $96 \%$ of which were women.

Time passed since graduation in Group A varied from 10 to 25 years, while the largest concentration (25\%) occurred in the group between 12 and 14 years. For Group B, time passed since graduation varied from 0 to 30 years and the largest concentration lay in the group of recently graduated persons ( $41 \%$ up to 5 years). 
Time on-the-job also indicates significant differences, that is, in Group A, current service time varied from 2 to 13 years, with the largest concentration (39.3\%) between 8 and 11 years on-the-job. In Group B, $63 \%$ had performed their current job for less than 4 years.

Table 1. Mean, standard deviations and standard errors of mean about age, years since graduation, years in the job and Student's T statistics

\begin{tabular}{ccccccc}
\hline Variable & Group & Subjects & Mean & $\begin{array}{c}\text { Standard } \\
\text { deviation }\end{array}$ & $\begin{array}{c}\text { Standard } \\
\text { error of } \\
\text { mean }\end{array}$ & $\begin{array}{c}\text { Statistics T } \\
\text { to tests of } \\
\text { mean }\end{array}$ \\
\hline Age & A & 28 & 38,61 & 4,366 & 0,825 & 0,035 \\
Years since & A & 70 & 35,36 & 7,547 & 0,902 & \\
graduation & B & 28 & 15,36 & 3,744 & 0,708 & 0,012 \\
Years & A & 28 & 11,55 & 7,527 & 0,893 & \\
in the job & B & 62 & 7,00 & 2,625 & 0,496 & 0,666 \\
\hline
\end{tabular}

In comparing the results of these 2 groups, a significant age difference is observed, with $\mathrm{T}=0,035$. Another significant difference is observed in time passed since graduation $(\mathrm{T}=0,012)$ in the two groups (Table 1$)$.

A positive linear correlation exists in the 2 groups between current time onthe-job and time passed since graduation. Thus, there are many more young people in Group B, with a concentration of those with little time on-the-job. It should also be highlighted that, in Group B, 1 out of every 4 subjects dedicated more than $85 \%$ of the time passed since graduation to their current job. In Group A, time passed since graduation is more than 10 years for $100 \%$, while $53,6 \%$ have less than 8 years on-the-job, thus revealing a higher degree of mobility.

In accordance with Group A, interest in the mental health area was high for $35,7 \%$ of the subjects, average for $42,8 \%$, low for $10,8 \%$ and $10,7 \%$ did not even respond. Nevertheless, only $0,2 \%$ took some kind of course in this area over the last 3 years. Group B nurses indicated high (33\%), average (18\%), low interest $(41 \%)$ and while $8 \%$ did not even respond. The demonstration of this interest by means of special courses over the last 3 years was low (12\%), although higher than in Group $\mathrm{A}(0,2 \%)$.

Nursing knowledge and opinion about depression

Knowledge about depression

No significant statistical differences were observed between the knowledge of Ribeirão Preto nurses (Group A) and those in São José do Rio Preto (Group B). 
The average value for right answers in Group A was 7.3 and 6.7 in Group B, with identical mean values (7.0) when applying the Mann Whitney test.

Table 2. Results of knowledge score about depression in 12 questions answered by nurses from Group A (Ribeirão Preto) and Group B (São José do Rio Preto)

\begin{tabular}{|c|c|c|c|c|c|c|c|c|c|c|c|c|}
\hline \multirow[b]{3}{*}{ Questions } & \multicolumn{10}{|c|}{ Options } & \multirow{2}{*}{\multicolumn{2}{|c|}{$\begin{array}{c}\text { No } \\
\text { answer }\end{array}$}} \\
\hline & \multicolumn{2}{|c|}{1} & \multicolumn{2}{|c|}{2} & \multicolumn{2}{|c|}{3} & \multicolumn{2}{|c|}{4} & \multicolumn{2}{|c|}{5} & & \\
\hline & $\mathrm{R} \mid \mathrm{BP}$ & SJRP & RIBP & SJRP & RIBP & SJRP & RIBP & SJRP & $\mathrm{R} \mid \mathrm{BP}$ & SJRP & RIBP & SJRP \\
\hline Epidemiology & 2 & 12 & - & - & 2 & 6 & 1 & 2 & 21 & 44 & 2 & 9 \\
\hline Diagnosis & - & - & 17 & 59 & 3 & 4 & 5 & 9 & - & - & 3 & 1 \\
\hline Behavior & 13 & 34 & - & - & - & - & 13 & 30 & 1 & 8 & 1 & 1 \\
\hline Treatments & - & 3 & - & 1 & 6 & 9 & 8 & 23 & 8 & 28 & 6 & 9 \\
\hline Psychotherapies & 1 & - & 4 & 25 & 7 & 9 & 3 & 8 & 12 & 25 & 1 & 6 \\
\hline Associated situations & - & 10 & 3 & 3 & - & 1 & 25 & 57 & - & 1 & - & 1 \\
\hline Diagnostic criteria & - & 3 & - & 8 & - & - & 15 & 47 & 9 & 12 & 4 & 3 \\
\hline Secondary effects & 3 & 18 & - & 1 & 1 & 2 & 17 & 37 & 1 & 5 & 6 & 10 \\
\hline Risk groups & - & 1 & - & 1 & - & - & - & 3 & 28 & 66 & - & 2 \\
\hline Signals & 5 & 28 & 1 & - & - & - & - & - & 22 & 44 & - & 1 \\
\hline Other symptoms & 1 & 7 & - & - & - & - & 2 & 4 & 25 & 60 & - & 2 \\
\hline Nurse behavior & - & 1 & - & 2 & - & 5 & - & 1 & 28 & 64 & - & - \\
\hline
\end{tabular}

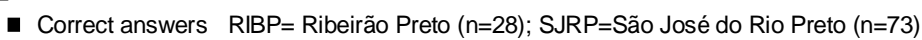

Most nurses demonstrated they have average knowledge (86 \% in Group A and $58 \%$ in Group B) and very good knowledge (3\% in Group A and $34 \%$ in Group B). However, little knowledge about depression is still found in $11 \%$ of group A and $8 \%$ of group B. This means that only $1 / 3$ of the population attended in São José and $3 \%$ in Ribeirão Preto would be under the care of nurses with very good knowledge about depression.

Viewpoints about depression

In comparing the opinion of nurses in both cities about depression, no significant differences were observed, in theirs whole results. The Mann Whitney test respectively showed a 6.32 and 6.29 average variation for groups A and B with 6.4 and 6.5 as the mean values.

Table 3. Opinion level about depression of interviewees in groups $A$ and $B$

\begin{tabular}{cccccc}
\hline Scores & $\begin{array}{c}\text { Opinion about } \\
\text { depression } \\
\text { level }\end{array}$ & Group A & Group B \\
\hline 0 to 2.9 & Low & - & $\%$ & No. & $\%$ \\
\hline 3.0 to 4.4 & - & 1 & 3.6 & 2 & 2.7 \\
4.5 to 6.0 & Average & 10 & 35.7 & 27 & 37.0 \\
6.1 to 7.4 & - & 14 & 53.6 & 37 & 50.7 \\
7.5 to 9.0 & High & 3 & 7.1 & 7 & 9.6 \\
\hline Total subjects & & 28 & 100 & 73 & 100 \\
\hline
\end{tabular}


Standard deviation is greater in Group A (0.884) than in Group B (0.991) and 0.781 variance in Group A is much smaller than in Group B (0.983). Differences between subject numbers may have caused the difficulty to perceive possible differences between the opinion of the two groups analysed.

In Table 3, it is observed that 17 subjects in Group A(60,7 \%) and 44 in Group B $(60,3 \%)$ presented scores between 6.1 and 8.1. The general viewpoint in both groups is in accordance with the expected result. 11 intermediary answers occurred in Group A and 29 in Group B. None of the scores was below 3.9.

\section{DISCUSSIÓN}

The nurses in this study who had been graduated for more than 10 years $(100 \%$ for Group A and $50 \%$ for Group B) probably did not hear about any other alternatives for mental illness except for the psychiatric hospital/asylum.

Studies realized by nurses in the last decades showed that teaching still centers on the clinical view and the student's only learning sphere is the lunatic asylum(1213). The low level of interest in the specialty is related to stigma, to the peculiarly traumatic contact in undergraduate training, as well as to the limited availability of courses and the lack of stimulus that nursing receives for seeking updating and new knowledge.

Group B nurses estimate that between 20 and $50 \%$ of the persons they assist at the services they work at are victims of depression. Nevertheless, only $17,8 \%$ of the nurses oriented $10 \%$ of the cases identified with depression. In Group A, nurses estimate that there are many depressed persons (between 20 and $60 \%$ ) that attends basic health services but $68 \%$ of them are not oriented towards specialized care.

It was verified that $31 \%$ of the nurses from the Group B did not give any response about depressed patient care. In group A, this absence of answers was also frequent $(36 \%)$. It gives rise to the supposition that 1 : the nurses do not have any direct contact with the population attended at the service; 2 - they are not identifying the presence of depression in people they are caring for; may occur negation and consequent distancing in relation to those persons «disturbing» or that cause anxiety.

The large majority of the subjects $(90,4 \%)$ in both groups agrees that the nurse has the necessary conditions to detect depressed patients in daily work. 
However, little is done in practice. Justifications include lack of time, excessive work load, lack of specialized support for treating and orienting patients with complex problems. This justification may be concealed by the lack of adequate knowledge, as indicated by PAHO/WHO (1) and other studies (10-14).

Although the groups do not present significant differences in global knowledge, differences between some points are verified when realizing a qualitative interpretation and analysis.

In Table 2, question $\mathrm{N}^{\mathrm{o}} 4$ stands out, in relation to which $12,3 \%$ did not answer which medical treatment would be indicated to improve the clinical picture. Moreover, 34,4 \% indicated medication for symptomatic relief, demonstrating lack of knowledge about the therapeutic value of antidepressives and stimulating hypermedication.

With respect to psychological treatment indications, the existence of errors and lack of information was disclosed in Group B $(68,4 \%)$ and part of Group A $(34,2 \%)$. Their options were concentrated in psychoanalysis and short therapy, leaving out cognitive and interpersonal therapies, which are effective in depression treatment.

On the basis of these answers, we also infer that nurses do not know about their own role as therapists, in view of the fact that interpersonal relations allow their professional performance to have a therapeutic function.

Nurses in the 2 groups ( $\mathrm{A}=87,7 \%$ and $\mathrm{B}=100 \%)$ agree that the nurse must carefully listen to the patients' complaints, help them to become aware of their condition, reinforce the importance of specialized therapies and support them in positive attitudes. However, the $6,8 \%$ in Group B who chose to merely reinforce the specialist's therapeutic behavior omit their participation in this process, suggesting self-exclusion, professional submission and lack of knowledge about their therapeutic potential.

When analyzing the contents of opinion test questions, it should be highlighted that $32 \%$ of group A and $40 \%$ of group B did not display a favorable attitude towards attending the person with depression, at the primary level.

Persons in Group A (68 \%) as well as in Group B $(60 \%)$ believe that caring for depressed patients is a pleasant task. Furthermore, $29 \%$ of the nurses in Group B are indecisive. This indicates these subjects' lack of experience since 
nurses who have already assisted a depressed patient know how difficult and consuming this task is.

High agreement rates occurred in Group A and B about the importance of investing in depressed patient care as well as the nursing contribution to decreased suicide risk among these patients (96\% in Group A and $62 \%$ in Group B).

The test detected incoherence between practice and theory. The nurses did not agree that "assisting depressed patients is a waste of time". This opinion includes the belief that the disease can be cured or at least controlled.

On the other hand, the nurses allege that they do not provide this assistance due to a lack of time. It is known that service management highly depends on the nurses, their knowledge, competency and the professional values that guide their actions. These nurses do not clearly perceive the strength and power of their management and therapeutic position. Only $54 \%$ in Group Aand $53 \%$ in Group B totally agree with the nursing contribution towards improving adhesion to treatment with antidepressive medication.

The position of the nurse can be of vital importance for the attitude of the whole team in detecting the signals and symptoms pointing towards depression, in adequately treating the cases (identified, under treatment or rehabilitation) as well as in the appropriate guidance towards specialized care $(1,8,12-14)$.

In comparing the present study subjects, who are working in the basic health network of Ribeirão Preto (Group A) and São José do Rio Preto (Group B), we found in Group A nurses oldest than in Group B with less time since graduation for Group A.

A linear correlation was observed between time since graduation and time on-the-job, in spite of a higher mobility level in Group A.

Displays of interest in the mental health area do not coincide with the answers indicating search for knowledge and improvement. The greater search for courses among Group B subjects may be related to the younger age of group members.

Subjects admit that the nurse is professionally able to detect, guide and assist the depressed patient. Nevertheless, they demonstrated high omission rates in taking an adequate participative attitude. 
No significant differences in knowledge about depression occurred between the 2 groups. However, the existence of errors and lack of information was observed with respect to depression identification and treatments.

Global results in relation to viewpoints did not reveal any significant differences between the 2 groups either. Nevertheless, incoherence is observed between theory and practice, since they recognize the importance of nursing actions in detecting cases and assisting depressed patient but reveal a clear lack of experience for realizing this task.

These results support the initial premise that motivated this study: nurses active at basic health care services do not have sufficient knowledge about depression and their opinions are not in accordance with current advances in terms of psychiatric reform and health care system.

We recommend investments in the formal education of new nurses and in the education and updating of practicing professionals

Acknowledgements. Project financed by OPAS-BRA/AMP/61/0380/2000C and CNPqProc. 520277/96.

\section{REFERENCES}

1. OPS/OMS - Organização Panamericana de La Salud/Organización Mundial de La Salud. Programa de Salud Mental. División de Promoción de la Salud. Modelo para la capacitación de la enfermera general en la identificación y manejo de los transtornos afectivos. Generalista I, OPAS: Washington (USA);1999.

2. Fleck MPA, Lima AFBS, Louzada S, Schestasky AH, Henriques A, Borges VR, et al. GRUPO LIDO. Associação entre sintomas depressivos e funcionamento social em cuidados primários à saúde. Rev Sau Púb 2002; 36(4): 431-8.

3. Kapzinski F. Bases biológicas dos transtornos psiquiátricos. Porto Alegre (RS): Artes Médicas; 2000.

4. Dalgalarrondo P. Psicopatologia e semiologia dos transtornos mentais. Porto Alegre (RS): Artes Médicas; 2000.

5. Santiago NJ, Klein DN. Dysthymia and chronic depression: introductions classification, risk factors, and course. J Clinic Psychol 2003; 59: 807-861.

6. Andrews G, Szabo M, Burns J. Preventing major depression in young people. British J Psych 2002; 181: 460-2

7. Montgomery S. Confrontando la depresión. Guia del médico. New York (USA): Pfiser International; 1997.

8. WHO. World health Organization. Saúde mental: nova concepção, nova esperança. Lisboa (Por: CLIMEPS;2002.

9. Amarante PDC. O homem e a serpente. Rio de Janeiro (RJ): FioCruz; 1996.

10. Saraceno B. Libertando identidades: da reabilitação psicossocial à cidadania possível. Rio de Janeiro (RJ): TeCorá; 1999.

11. Pitta A.(Org.). Reabilitação psicossocial no Brasil. São Paulo (SP): Hucitec; 2001. 
12. Fraga MNO. A prática de enfermagem psiquiátrica: subordinação e resistência. São Paulo (SP): Cortez; 1993

13. Esperidião $E$, Munari $D$. Holismo só na teoria: a trama dos sentimentos do acadêmico de enfermagem sobre sua formação. Rev Esc Enf USP 2004; 38(3): 332-340.

14. Silva MCF, Furegato ARF, Costa Jr ML. Depressão: pontos de vista e conhecimento de enfermeiros da rede básica de saúde. Rev Latino-am Enfermagem 2003; 11(1): 7-13. 